\title{
Reconstructing Kenya's Educational Philosophy to steer attainment of the Sustainable Development Goals and Kenya's Vision 2030 Plan
}

Kisirkoi Florence ${ }^{\mathrm{a}}$, Kariuki Michael ${ }^{\mathrm{b}}$, Kadenyi Misia Anne ${ }^{\mathrm{a}}$

aMaasai Mara University Kenya, ${ }^{\text {b} M o i ~ U n i v e r s i t y, ~ K e n y a ~}$

\section{Vol 1 No 12019}

ISSN: 2788-6298

DOI: https://doi.org/10.35293/tetfle.v1i1.64

\begin{abstract}
Philosophy of education in Kenya needs to be constantly reconstructed given the emerging needs of society and in light of global trends. Changes in the education system over time have not eradicated education challenges that result in unemployment and social evils in Kenya. There are also global and national goals to be met. The objective of this study was to examine the role of philosophers and suggest whether professional philosophers could reconstruct philosophy of education in Kenya to guide the achievement of Sustainable Development Goals (SDGs) and the Kenya Vision 2030 Plan. The SDGs and Kenya's Vision 2030 work in tandem, and if effectively and efficiently implemented, guided by a sound philosophy of education, lives of all Kenyans would be raised to international standards. This study was conducted as desk research that employed critical conceptual philosophical literature review. A recommendation was made that experts in philosophy of education could use Dewey's philosophy of pragmatism to facilitate the reconstruction of Kenya's national philosophy of education as a tool to steer attainment of the Sustainable Development Goals and the Kenya Vision 2030.
\end{abstract}

Keywords: Sustainable Development Goals (SDGs), Kenya Vision 2030, philosophy, Dewey's pragmatism, philosophy of education 


\section{Introduction}

Due to societal dynamism and global trends, philosophy of education in Kenya needs to be constantly reconstructed to remain relevant. Education in Kenya has not solved many societal problems in spite of many changes over time. In addition there are international and national development goals to be achieved through education which is viewed as the tool through which Kenya will achieve Vision 2030 (Republic of Kenya, 2007), the country's development blueprint constructed to steer the achievement of the Millennium Development Goals (MDGs) and the later Sustainable Development Goals (SDGs).

\section{Statement of the problem}

Education in Kenya since independence has been undergoing changes, but there are similarities in the inadequacies of the outcome soon after implementation each time. There has been a number of commissions looking into the education agenda for Kenya, which came up with laudable reports such as the Ominde Report (Ominde,1964); Republic of Kenya (1982) and (Koech,1999) leading to the changes of the education system from seven years primary education, four years secondary education, two years higher secondary education and three years university education referred to as 7.4.2.3. It was changed to the outgoing eight years primary education, four years secondary education and four years university education referred to as 8.4.4 and currently it is changing to the incoming two years pre-school education, six years lower primary, three years upper primary, three years secondary and three years tertiary education referred to as 2-6-3-3-3 education system which is Competency-Based. All the commissions of education were constituted to provide the best education system for the country but unemployment and "evils" such as corruption, inequalities, impunity, tribalism and greed practised by even educated people persist. The first goal of education in Kenya states that "education should promote national unity" (MOEST, 2002) yet schools do not reflect national unity. They are in categories such as national, county, boarding, and day schools with varied infrastructures, financial and teacher provision, climatic conditions, and school 


\section{K. FLORENCE ET AL.}

facilities. Yet all children take the same national examination and compete for the same job opportunities.

The 7-4-2-3 system of education was introduced in 1964 soon after independence in 1963 but was found to lead to white collar jobs and joblessness. It was changed to 8-4-4 which also led to joblessness and was blamed for societal ills. It is changing to 2-6-3-3-3. Some educated people end up unemployed and unemployable and do not utilise the knowledge acquired and developed over a long time. Examinations have been used as a selection and elimination criteria with no regard to those who do not get selected anywhere. Are the philosophers playing their role in guiding development of a holistic democratic curriculum in Kenya where the society's real problem of life is addressed as advised by Dewey (1916, p.115) and later Njoroge and Bennaars (1986); who stipulated that in a holistic education the learner should acquire the cognitive skills which entail knowledge acquisition and utilization?

\section{The objective of this study}

The objective of this study was to examine the role of philosophers and suggest how professional philosophers could reconstruct philosophy of education in Kenya to enable education to guide achievement of the Sustainable Development Goals and the Kenya Vision 2030.

\section{Methodology}

This study was qualitative desk research, which employed critical conceptual philosophical review of literature of philosophy of education and detailed description and explanation of philosophical issues in relation to education in Kenya. It explored the role of philosophers, Dewey's pragmatic philosophy, Education Commissions in Kenya, the Kenya Vision 2030 and the SDGs.

\section{National philosophy of education}

A country's philosophy of education is an ideology that controls education policy-making and organisational procedures, hence it requires constant redefining and detailed scrutiny 
of its diverse meanings. Writing on Philosophy of Education as a theoretical framework, Wainaina (2006, p. 133) defines 'Philosophy of education' as 'a general principle, a theoretical framework, which is expected to guide and inform educational practices'. This definition is akin to Dewey's definition of philosophy as 'the general theory of education' (Dewey, 1916, pp.328, 331) or better still 'philosophy is the theory of education as a deliberately conducted practice' (Dewey 1916, p.332). Wainaina relates philosophy of education to a national system of education:

"In every country, an educational system is usually based on a conceptual framework that is more general than one that guides activities at a particular educational institution. Within that framework, the main educational goals, the methods of achieving those goals and the methods of determining whether or not the goals have been achieved are specifically defined" (2006, p.133).

In addition, Dewey's states that "If we are willing to conceive education as the process of forming fundamental dispositions, intellectual and emotional, towards nature and fellow men, philosophy may even be defined as the general theory of education" (1916, p. 334); it captures the essence of philosophy of education as an ideology. 'An appropriate education system of a country is founded on an appropriate philosophy which targets goals pursued through clearly stated objectives' (Republic of Kenya, 2012, par.2.1). While discussing Philosophy of Education as a sub-discipline of knowledge Wainaina, states:

"In actual sense, philosophy of education is an area of study which attempts to specialise at addressing philosophical issues and problems within the field of education. This means that although the issues addressed are philosophical in nature, they occur in a specific social sector, we identify with the activities of teaching and learning" (2006, p.134).

This assertion concurs with Dewey's view that 'philosophical problems arise because of widely felt difficulties in social practice' such as in education. Dewey $(1916, p .334)$ is 


\section{K. FLORENCE ET AL.}

emphatic that an 'educational point of view enables one to envisage the philosophic problems where they arise and thrive in practice.' By referring to 'activities of teaching and learning' as the context from which 'philosophical issues and problems' are addressed in philosophy of education; that view is consistent with Dewey's perspective on the point at which 'the intimate connection between philosophy and education appears' (Dewey 1916, p.328). There is a distinction between philosophy of education as an academic activity and philosophy of education as an ideology that guides education. The Koech (1999) Report calls for construction of a national philosophy of education in Kenya rather than just have a set of ideas of national philosophy of education

"As the nation enters the new millennium, it is imperative that a coherent Afrocentric philosophy of education be formulated to guide both the content and methods of the entire curriculum design and practice. Time has now come for us to define ourselves in our own Kenyan way. To understand and accept ourselves as Kenyans demand that we revisit our historical and philosophical roots with a new vision" (Republic of Kenya, 1999, 1.3.5).

Njoroge and Bennaars (1986) state that after independence, African leaders advocated for 'authenticity in African educational thought' ( $p .70)$. The leaders articulated various national philosophies of education either directly as in Tanzania or indirectly as was the case in Kenya. These philosophies of education are 'clearly evident from the numerous reports and policy papers on education' (1986, p. 71). For instance, 'the Ominde Report (Republic of Kenya,1964) as well as subsequent reports' are said to stress 'respect for African traditional values in reaction to colonial brainwashing that everything from African tradition was evil.' This is regarded as conservative educational thought yet it is paradoxical when put along with progressive thought which requires 'change and progress.' The Ominde Report asserted that education is a function of the nation and it does not have its own goals. Other conservative educational principles are the idea of African Socialism based on the traditional values of mutual social responsibility and political democracy (Njoroge \& Bennaars, 1986, p.70-71). The conservative philosophy of education is concerned with African traditional values and traditional social ethics in 
the area of education. The Progressive philosophy of education is expressed directly or indirectly by scholars and national leaders in Africa who advocated for educational reform for purposes of 'rapid social, economic and political development' (1986, p. 72).

\section{Exploration of Philosophy of Education}

Philosophy of education is analysed by distinguishing its various meanings. For instance, it is distinguished as general and technical, and further technical philosophy of education is distinguished as a process and as a product (Njoroge \& Bennaars 1986; Akinpelu 1981; Brauner. \& Burns, 1965). Griffiths (2010) distinguishes philosophy of education as either methods or systems of education. Soltis (1998) distinguishes three dimensions of philosophy of education namely personal, public and professional. Philosophy of education as a process is an activity of scholarly study which employs what Griffiths (2010) calls the four functions of philosophy namely the analytic, the evaluative, the speculative and the integrative functions in the study of education (as cited by Brauner \& Burns, 1965, p.23).

Njoroge and Bennaars (1986, p.23, 100) also identified four functions of technical philosophy used in philosophy of education; namely, the rational, critical, existential and speculative functions. The four functions of technical philosophy become four approaches in technical philosophy of education; these are analytical, critical, phenomenological and implication approaches. Technical philosophy of education is, therefore, an area of academic, professional and scholarly specialisation (Njoroge \& Bennaars, 1986, p. 41). In this sense technical philosophy of education is a technical activity undertaken by professional philosophers of education; it is 'the process of philosophising about education' (Brauner \& Burns, 1965, p.23). Scheffler (1966) illustrates the analytical function of the technical philosopher of education and argues that 'educational activity is articulated, organised, and executed with the aid of clusters of concepts' (p.15).

Some concepts which explain the philosophy of education are specialised others are general. Without elaborating on his reasons, Scheffler (1966) states that it is 'the general concepts that attract the philosopher's attention.' These general concepts feature 'widely in description of fundamental processes, institutions, or ideologies; in formulation of basic 


\section{K. FLORENCE ET AL.}

goals and programs; in inference and argumentation underlying important decisions.' They are 'intimately related to the quality and direction of educational activity' (p.15). The general concepts as described by Scheffler (1966) seem to denote what Soltis (1998) calls the 'public dimension of philosophy of education' or what commissions of education in Kenya and Sessional Papers on education formulate as ideological national philosophy of education for the country.

Scheffler (1966) therefore helps to clarify what this study proposes to do regarding the formulation of a philosophy of education; to guide education towards the realisation of SDGs and Vision 2030 in Kenya. This is because the role of the professional philosopher of education in relation to general concepts of education is to try to see if and how philosophies make sense when subjected to systematic and impartial scrutiny conducted far from the heat of action. Such analysis is significant in education; it may facilitate the discovery of weak assumptions and control analogies usually suppressed in practice and expose normally unnoticed confusions. It may suggest fruitful comparisons and improved ways of thinking about education' $(1966,15)$. Technical philosophy of education greatly differs from general philosophy of education.

\section{General Philosophy of Education}

Unlike technical philosophy of education, general philosophy of education is expressed by non-experts and non-specialists in technical philosophy of education, and it is as old as when people started to express their general ideas and thoughts about education, its nature, purpose and goal for the society. It includes comments, beliefs, statements and ideas about education, views of opinion leaders like politicians, journalists, civil society, religious leaders and other advocacy bodies. Others include sets of ideas on education by political parties such as Harambee and Nyayoism in Kenya. General philosophy of education also includes educational ideas of theorists and researchers who are not technical philosophers of education such as John Locke, Kant and Hegel (Phillip \& Siegel, 2013). It may also include activities of 'philosophers who sometimes illustrate some general theme by reference to educational concept' (Hirst \& Peters, 1998, p.37). Other general philosophies are statements of vision, mission and mottos of institution of learning 
like universities, secondary or primary schools (Akinpelu, 1981) such as the motto of Starehe Boys secondary school in Kenya - NatulengeJuu which means 'Let's Aim High!' In addition, there are general statements purported to be philosophy of education by International bodies on education, for instance, the United Nations and its agencies. Thus, the SDGs constitute general philosophy of education particularly for those goals which relate to education. The proponent of general philosophy of education does not intend their 'philosophies of education' to be subject of scrutiny or to contribute to academic discourse on philosophy of education.

\section{Dimensions of Philosophy of Education}

Philosophy of education is distinguished along three dimensions, namely personal, public and professional dimensions of philosophy of education (Soltis, 1998). The personal dimension of philosophy of education connotes a set of individual's beliefs about what is good, right and worthwhile in education.

The public dimension of philosophy of education refers to an educational proposal meant as a normative prescription to guide and direct the practice of education for the nation. This is the pragmatic philosophy of education found in Plato's Republic or Dewey's philosophy of education. It avails opportunity for thoughtful participation in the direction education should take; a concern by all who care seriously about education. The public dimension of philosophy of education is akin to what commissions of education and Sessional Papers in Kenya formulate as philosophy of education for the country. The public dimension of philosophy of education includes educational proposals, debates, critiques, programmes and policy-making meant to influence the entire system of education.

The professional dimension of philosophy of education refers to activities and output by scholar-teachers trained in philosophical skills. They adhere to professional canons of scholarship and use the technical tools of the professional philosophers in dealing with conceptual and normative issues relevant to education' (Soltis,1998, p.198). Their activities include analysing, reflecting, evaluating and seeking a clearer understanding of 


\section{K. FLORENCE ET AL.}

educational matters. They attempt to ascertain the logical soundness of arguments, explicating the meaning of ideas, justifying value claims, constructing reasonable arguments and providing ways to think about educational tasks and problems. This is educational philosophising which additionally includes providing illumination and perspectives for educators to 'think with' (1998, p. 199).

The aim of educational philosophising is "to make the educational enterprise as rationally self-reflective as possible by providing philosophically rigorous examinations, critiques, justifications, analyses and syntheses of aspects of the educators' conceptual and normative domain' (Soltis, 1998, p. 199). Professional philosophers are expected to provide 'coherent and comprehensive statements of a public philosophy of education' (Soltis, 1998, p.197). Soltis (1998, p.199) advises that professional philosophers of education have 'a moral obligation to use their skills in the public sphere' of philosophy of education.

There are three senses in which a professional philosopher of education can 'go public' in philosophy of education. These are firstly by attempting 'to put a philosophical point, argument or message before a 'public' (Soltis, 1998, p.199). This can either be by (a) presenting or publishing a scholarly paper to be heard by a small audience or by (b) using mass media to reach 'the public at large' for example through the use of television, newspapers or other popular media. The second sense of going public is by 'public policy.' This is whereby professional philosophers of education co-operate with others 'on explicit policies emanating from official commissions, committees and agencies.' Such public policies are 'official' by being 'authorised or legitimated by socially sanctioned institutional devices' (Soltis, 1998, p.200). Soltis believes that professional philosophers should increasingly serve as 'co-workers on this policy-making level:

"They need to put themselves forward in this capacity more vigorously and the public need to more clearly see what they distinctively have to offer as professionals with special skills. Mismatched expectations do not help here at all" (1998 p.200). 
Professional philosophers should, therefore, move beyond the academics to engage with policy-makers in educational ministries and other relevant government agencies. On the other hand, the government as public agency should match the professional specialised skills and expertise of philosophers of education with public needs in order for them to contribute to 'an educational system that fulfils desirable purposes' (Soltis, 1998, p. 200). The other sense of a professional philosopher of education going public is by 'public ideology,' which refers to conscious and unconscious beliefs, values or purposes of education and schooling. The professional philosopher of education is required to 'unearth, examine, critique or attempt to justify public ideological commitments or to put it like Dewey articulate a new form of public ideology' (Soltis, 1998, p.200).

The public dimension of philosophy of education provides an additional view of general philosophy of education. Speaking of himself and other professional philosophers of education Soltis (1998, p.200) asserts that 'relevance of what we do to education must be the prerequisite of our commitment.' This includes substantive interaction and contact with educational researchers, professional educators and practitioners. However, this requires that professional philosophers of education 'keep their minds open to potentially relevant philosophical problems, issues or ideas' in public philosophy of education (Soltis, 1998, p.200). Soltis (1998) provides a provocative perspective of how professional philosophers of education can 'go public.'

Professional philosophers of education in Kenya can go public in the sense of analysing, reflecting, evaluating and seeking clearer understanding of philosophy of education as formulated in official policy documents on education such as reports by commissions of education in Kenya. The professional philosopher of education can attempt to ascertain the logical soundness of arguments, explicating the meaning of ideas, justifying value claims, constructing reasonable arguments and providing ways to think about educational philosophy in Kenya. 


\section{K. FLORENCE ET AL.}

Formulations of philosophy of education by commissioners in national reports on education in Kenya are interpreted as philosophical ideologies on education based on the wisdom of the commissioners. The critical philosophy is second order activity of reason that reflectively and critically analyses first order ideologies and wisdom. It appraises them by examining their justification and rational grounds. Their limitations and strengths are objectively made explicit. Philosophy of education in public sense is ideological, or it is an expression of the wisdom of those who produce it, but the professional philosopher of education must engage in a critical sense of philosophy, evaluative analysis of wisdom and ideology as they relate to education.

John Dewey explains that when in the course of doing something one encounters a difficulty which becomes an obstacle to be overcome before behaviour can be unified into a successful ongoing:

"The experienced difficulty is a perplexity, shock, confusion, perturbation, uncertainty and puzzlement. But a new impulse is stirred which becomes the starting point of an investigation, a looking into things, a trying to see them, to find out what is going on. Habits which were interfered with begin to get new direction as they cluster about the impulse to look and see" (Dewey, 1930, p. 181-182).

The search for a solution to an educational problem involves reflective thought captured by Dewey in the statement that: 'the problem fixes the end of thought and the end controls the process of thinking' (Dewey, 1933, p. 12). Reflective thinking begins in 'a forked-road situation' which is ambiguous and uncertain. In this case, one is awakened from dogmatic slumber of ordinary habitual behaviour. The problem evokes a person to reflective thought. In this case, Dewey (1933, p.11) asserts: "Demand for the solution of a perplexity is the steadying and guiding factor in the entire process of reflection."

Reflective thinking aims at solving a practical or real problem. It is thinking which is 'occasioned by an indeterminate situation. Its primary goal is to define the problem and 
to suggest methods for dealing with it. For Dewey, reflective thought is the essence of philosophy. Dewey defines philosophy as 'a form of thinking, which finds its origin in what is uncertain in the subject matter of experience, which aims to locate the nature of the perplexity and to frame hypotheses for its clearing up to be tested in action' (Dewey 1916, p. 331).

\section{Sustainable Development Goals, the Kenya Vision 2030 and Dewey's Pragmatic Philosophy of Education}

To reform education, it requires fundamental rethinking to avoid mere veneer reforms and Dewey's philosophy of pragmatism tends to shed light. According to Dewey $(1917,5)$, 'pragmatic philosophy means that philosophy shall develop ideas relevant to the actual crises of life, ideas influential in dealing with them and tested by the assistance they afford.' Philosophy of pragmatism focuses on learning by doing as an alternative to rote learning and strict teaching. The philosophy of pragmatism is based on what is a good society, and the right way of life and teachers need to know that what works for one child may not work for another, emphasising individualised teaching and learning (Khasawneh, Miqdad, \& Hijaz, 2014). Education in Kenya needs the guidance of pragmatic philosophy to address the actual crises of life faced by the country where there are social evils and joblessness regardless of changes made in the education system.

The United Nation's assembly developed the seventeen SGDs built on earlier MDGs as a blueprint. The goals are for the global transformational vision of human existence to redress the maladies that continue to afflict the human race and the environment (UN, 2015, art. 7). The goals seek to achieve what the MDGs failed to realise (UN, 2015, art. 5), thus SDGs are a recommitment to the realisation of MDGs (UN, 2015, art. 16). This suggests a philosophy of pragmatic reconstruction and expansion of experience which increases capacity to control subsequent experiences to realise SDGs as part of Vision 2030. 


\section{K. FLORENCE ET AL.}

The SDGs are supposed to guide as a reference point for development agenda of nations of the world for the next fifteen years (UN, 2015, preamble). Education is a tool to achieve all the goals which are stated as follows (UN, 2015, p. 14):

Goal 1. End poverty in all its forms everywhere; 2 . End hunger, achieve food security and improved nutrition and promote sustainable agriculture; Goal 3. Ensure healthy lives and promote well-being for all at all ages; Goal 4. Ensure inclusive and equitable quality education and promote; Lifelong learning opportunities for all; Goal 5. Achieve gender equality and empower all women and girls; Goal 6. Ensure availability and sustainable management of water and sanitation for all; Goal 7 Ensure access to affordable, reliable, sustainable and modern energy for all; Goal 8. Promote sustained, inclusive and sustainable economic growth, full and productive employment and decent work for all; Goal 9. Build resilient infrastructure, promote inclusive and sustainable industrialisation and foster innovation; Goal 10. Reduce inequality within and among countries; Goal 11. Make cities and human settlements inclusive, safe, resilient and sustainable; Goal 12. Ensure sustainable consumption and production patterns; Goal 13. Take urgent action to combat climate change and its impacts; Goal 14. Conserve and sustainably use the oceans, seas and marine resources for sustainable development; Goal 15. Protect, restore and promote sustainable use of terrestrial; ecosystems, sustainably manage forests, combat desertification, and halt and reverse land degradation and halt biodiversity loss; Goal 16. Promote peaceful and inclusive societies for sustainable development, provide access to justice for all and build effective, accountable and inclusive institutions at all levels; Goal 17. Strengthen the means of implementation and revitalise the Global Partnership for Sustainable Development.

The Kenya government launched its development agenda, the Kenya Vision 2030 in 2007 (Republic of Kenya, 2007) which meant to be a vehicle for accelerating transformation of Kenya into a rapidly industrialising middle-income nation by the year 2030. In achieving Kenya Vision 2030, all 17 SDGs would be accomplished. The education sub-sector, positioned under the social pillar, is a primary instrument in Vision 2030. For instance, by producing citizens with requisite knowledge, skills, competences, values, principles and 
attitudes instrumental for Vision 2030. Article 1.3 of Sessional Paper No. 1 of July, 2012 states:

"Kenya Vision 2030 places great emphasis on the link between education and the labour market, the need to create entrepreneurial skills and competences.... It articulates the development of a middle-income country in which all citizens will: have embraced entrepreneurship, be able to engage in lifelong learning, perform more non-routine tasks, be capable of more complex problem-solving, be able to take more decisions, understand more about what they are working on, require less supervision, assume more responsibility, and as vital tools towards these ends, have better reading, quantitative reasoning and expository skills. This has considerable importance for the kind of education and training system required to deliver the requisite skills, competencies and attitudes. As such there will be need to address issues related to quality, service delivery, curriculum, relevance, teacher development and management at all levels as well as trainers in the areas of technology and entrepreneurial skill development".

The reformation of education is a continuation of a process which started after independence with the first education commission of 1964. Articles 1.17 to 1.20 Sessional Paper no 1 of 2012 outlines education policy evolution which has transformed education in Kenya since independence from British colonial imperialism. This policy evolution on education in Kenya is mainly under the impetus of government-appointed recommendations of education commissions which can be thought of as attempts to reconstruct national philosophy of education in independent Kenya. This is in tandem with Dewey's idea that pragmatically formulated philosophy of education be applied in the system of education through government intervention and machinery. The appointment of national Education Commissions or Committees is a normative practice of national governments. Commissions of Education are appointed to enquire into educational problems and search for solutions. 


\section{K. FLORENCE ET AL.}

Thus, commission reports that are inquiring into problems in education and making recommendations thereto presuppose a pragmatic working philosophy. This is because according to Dewey philosophy is defined 'in terms of the problems with which it deals'. Such 'problems originate in the conflicts and difficulties of social life' (Dewey, 1916, p.348). Thus, educational philosophy constructed by an Education Commission must emanate from educational problems which an Education Commission is appointed to address. Dewey further elucidates on how a philosophy of education ought to be formulated when he wrote:

"The philosophical systems which formulate these problems record the main lineaments and difficulties of contemporary social practice. They bring to explicit consciousness what men have come to think, in virtue of the quality of their current experience, about nature, themselves, and the reality they conceive to include or to govern themselves (Dewey,1916, p.349)."

SDGs and Kenya Vision 2030 reflect what people have come to think in virtue of their current experience about problems that need to be addressed for transformation and improvement of life in contemporary society. There is a need to reconstruct the experience of life in order to formulate an educational philosophy effective in guiding education to serve its role in both SDGs and Kenya's vision 2030.

Dewey's pragmatism philosophy point to learner-centred and teaching-learning strategies which are in tandem with the basic education Curriculum Framework which is competency based, learner-centred in nature and emphasis learner active involvement in their own learning.

\section{Conclusion and Recommendation}

To ensure comprehensive thinking about the realisation of both SDGs and Vision 2030, Kenya requires an education system that is reformed to fit this purpose. Kenya has also embarked on the implementation of the Basic Education Curriculum Framework which is competency based and needs guidance. This paper has argued for pragmatic, 
reconstructivist and integrationist philosophy of Dewey to serve as a guide in reconstructing a national philosophy of education in Kenya to further guide implementation of Vision 2030 and the SDGs.

\section{References}

Akinpelu J.A. 1981. An Introduction to Philosophy of Education. London: Macmillan.

Brauner C. J. and Burns H. W. 1965. Problems in Education and Philosophy. N.J.: Prentice Hall.

Dewey, J. 1916. Democracy and Education. An Introduction to the Philosophy of Education. N.Y.: The Free Press.

Dewey, J. 1930. Experience and Nature. $2^{\text {nd }}$ ed. Chicago: The Open Court Publishing.

Griffiths, M. 2012. Is it Possible to Live a Philosophical, Educational Life in Education? Nowadays? Journal of Philosophy of education Society of Great Britain. Vol.46, No. 3.

Hirst, P. H and Peters, R.S. 1998. Education and Philosophy in Philosophy of Education: Major Themes in Analytical Tradition. I. Edited by Hirst P. H and White Patricia. London: Routledge.

Hirst, P. H. 1996. The Demands of Professional Practice and Preparation for teaching, in: J. Furlong and R. Smith (eds) The Role of Higher Education in Initial Teacher Training. London: Kogan.

Hirst, P. \& Peters, R. S. 1970. The Logic of Education. London: Routledge and Kegan Paul.

Republic of Kenya. 2012. A Policy framework on Education and Training: Reforming Education and Training in Kenya. Sessional Paper No.1 of July 2012 Accessed 18/3/2019 http://planipolis.iiep.unesco.org/en/2012/policy-framework-educatio andtraining-reforming-education-and-training-kenya-sessional-paper

Republic of Kenya. 2007 Kenya Vision 2030 Com. A Globally Competitive and Prosperous Kenya. Nairobi: Government Printer. 


\section{K. FLORENCE ET AL.}

Republic of Kenya.1982. Report of the Presidential Working Party on the Second University [Mackay Report]. Nairobi: Government Printer.

Koech, D. K.1999 Totally integrated quality education and training (TIQET): Report of the Commission of Inquiry into the Education System of Kenya (Koech Report) Nairobi: Government Printer.

Njoroge R.J. \& Bennaars G.A. 1986. Philosophy and Education in Africa. An Introductory Text for Students of Education. Nairobi: University Press.

Ominde, S. H. 1964. Kenya Education Commission report (Ominde Report) Nairobi: Government Printer.

Passmore, J.A.1980. The philosophy of teaching. Duckworth: University of Michigan.

Scheffler, I. (ed) 1966. Philosophy and Education. Modern Readings. $2^{\text {nd }}$ ed. Boston: Allyn and Bacon.

Soltis, F. 1998. Perspectives on Philosophy of Education in Philosophy of Education: Major Themes in Analytical Tradition. II. Edited by Hirst Paul H and White Patricia. London: Routledge.

UN 2015. Transforming our World: The 2030 Agenda for Sustainable Development. Resolution Adopted by General Assembly on 25 September.

Wainaina, P. 2006. Introduction to Philosophy of Education in Themes in the Study of the Foundations of Education. Sifuna Daniel (ed). Nairobi: The Jomo Kenyatta Foundation. 